\title{
RESENHAS|REVIEWS
}

MARICATO, Ermínia. Formação e impasse do pensamento crítico sobre a cidade periférica Em: O impasse da política urbana no Brasil. Petrópolis, RJ: Vozes, 2011.

\section{A Cidade Periférica e As Influências Teóricas da Nova Escola Do Urbanismo BRASILEIRO}

\author{
The Peripheral City And Theoretical Influences Of Brazilian’s New School Of \\ URBANISM
}

Rodolfo Carvalho Neves dos Santos ${ }^{1}$

Como citar: DOS SANTOS, Rodolfo Carvalho Neves. MARICATO, Ermínia. Formação e impasse do pensamento crítico sobre a cidade periférica Em: O impasse da política urbana no Brasil. Petrópolis, RJ: Vozes, 2011. Scientia Iuris, Londrina, v. 25, n. 1, p. 200-202, mar. 2021. DOI: $10.5433 / 2178-8189.2018 v 22 n 2 p 200$. ISSN: $2178-8189$.

Resumo: Tem como objetivo apresentar as influências teóricas da chamada "Nova Escola do Urbanismo" responsável por proporcionar novas abordagens acadêmicas sobre a questão urbana no Brasil a partir da perspectiva da cidade periférica. Apresenta-se as duas matrizes teóricas que serviram de influência ao movimento: os marxistas franceses e os intérpretes sociais brasileiros, com destaque para Celso Furtado e Francisco de Oliveira. Parte-se do balanço feito por Ermínia Maricato em capítulo denominado "Formação e Impasse Do Pensamento Crítico Sobre A Cidade Periférica", que integra livro de sua autoria com o título "O impasse da política urbana", obra em que a autora avalia o ciclo de lutas e conquistas nos campos social, político e acadêmico que teve início durante a ditadura militar, mas que, após a criação do Ministérios das Cidades, em 2003, chega ao "fim do ciclo".

Palavras-chave: Política Urbana. Cidade Periférica. Nova Escola do Urbanismo.

Abstract: It aims to present the theoretical influences of the so-called "New School of Urbanism" responsible for providing new academic approaches on the urban issue in Brazil from the perspective of the peripheral city. The two theoretical matrices that served as influence for the movement are presented: French Marxists and Brazilian social interpreters, with emphasis on Celso Furtado and Francisco de Oliveira. It starts from the balance made by Ermínia Maricato in a chapter called "Formation and Impasse Of Critical Thinking About The Peripheral City", which integrates a book of her authorship with the title "The impasse of urban politics" where the author evaluates " cycle "of struggles and conquests in the social, political and academic fields that began during the military dictatorship, but which, after the creation of the Ministries of Cities, in 2003, announced the moment of" the end of the cycle".

1 Mestrando no Programa de Pós-Graduação em Direito Negocial da Universidade Estadual de Londrina. 
Keywords: Urban Policy. Peripheral City. New School of Urbanism.

O conceito de cidade periférica vai além do estudo da metrópole e das grandes cidades como denúncia da pobreza urbana; deseja-se estudar as cidades a partir das condições e estruturas próprias da periferia do capitalismo, isto é, apresentando o espaço urbano como relações sociais (MARICATO, 2011, p.102-105).

Ermínia Maricato (2011, p. 99-169), no capítulo denominado a "Formação e Impasse do Pensamento Crítico Sobre a Cidade Periférica" em seu livro "O Impasse Da Política Urbana", publicado em 2011, apresenta um balanço sobre a produção acadêmica que teve como objeto de estudo a realidade urbana brasileira dos últimos 40 anos, destacando que nesse período formou-se, no Brasil, a chamada Nova Escola do Urbanismo, "que alimentou a militância urbana e as gestões públicas democráticas nesse período" (MARICATO, 2011, p. 11), além de ter contribuído "para uma nova formulação teórica sobre a metrópole na periferia do capitalismo" (MARICATO, 2011, p. 102).

Este movimento foi responsável por pensar a questão urbana inserida na especificidade do capitalismo periférico brasileiro, tendo como influência duas matrizes teóricas principais: os teóricos marxistas franceses e os intérpretes sociais brasileiros (MARICATO, 2011, p. 121).

A primeira fonte teórica, os marxistas da Escola Francesa de Sociologia Urbana, propunham-se a dar mais destaque à realidade urbana como ela é, e não como ela deveria ser. Entre os expoentes mais influentes teve-se, Christian Topalov, que se dedicava ao estudo da propriedade imobiliária e dos promotores imobiliários como influenciadores da produção do espaço urbano; Jean Lojkine, que desenvolveu estudo sobre a teoria da urbanização capitalista, Alain Lipietz, que estudou a renda imobiliária; além de Edmond Preteceille e Henri Coing, que estudaram os conjuntos habitacionais (MARICATO, 2011, p. 122-125).

A segunda fonte de influência teórica para interpretação da cidade brasileira foram os próprios autores nacionais. Entre eles, haviam aqueles que estudaram as especificidades do capitalismo periférico, traçando uma teoria geral sobre quais as características essenciais acerca da inserção do Brasil no mercado internacional; outros, que se dedicaram ao estudo da originalidade da sociedade brasileira em suas raízes de formação. A autora destaca o trabalho de Caio Prado Jr., Celso Furtado, Raymundo Faoro e Antonio Cândido naquilo que chamou de "esforço obsessivo de buscar esquemas interpretativos sobre a realidade brasileira", além de Francisco de Oliveira, este, em especial, sendo aquele que proporcionou a "chave" metodológica mais eficaz para explicação da cidade brasileira (MARICATO, 2011, p. 126-127).

Segundo Maricato (2011, p. 128-130), Francisco de Oliveira e Celso Furtado proporcionaram uma nova interpretação da sociedade brasileira, apresentando categorias importantes para compreensão da cidade periférica. Celso Furtado é responsável por analisar a questão do desenvolvimento a partir da relação de dependência; Francisco de Oliveira, por seu turno, denuncia o dualismo até então presente na interpretação da realidade brasileira como tentativa de explicar o atraso econômico e as desigualdades sociais (o subdesenvolvimento) e a 
anunciação de que sua superação estava atrelada à modernização e integração dos setores atrasados ao processo de industrialização. A denúncia se deve ao fato de que, segundo Francisco Oliveira, a condição de subdesenvolvimento não decorre de uma polarização ou uma etapa de atraso, mas de condições e estruturas afetas ao rebaixamento do preço da força de trabalho e do restrito mercado de bens de consumo básico (como moradia e alimentos). Nessa mesma linha de crítica também figuram Paul Singer e Milton Santos.

Outro elemento importante para explicação da sociedade brasileira e da realidade urbanística é a existência de uma "burguesia retrógrada" que deu à tônica ao processo de urbanização do Brasil, principalmente por intermédio do aparelho estatal, mantendo-se as raízes da sociedade escravocrata, patrimonialista, patriarcal e clientelista. Esta condição influencia diretamente na forma como a legislação urbanística brasileira não é efetivamente aplicada em determinados espaços urbanos: há um grande corpo regulatório, mas um escasso aparato fiscalizatório, sujeito às influências diversas, como práticas clientelistas. Essa sociedade é explicada a partir das obras de Florestan Fernandes, Sergio Buarque de Holanda e Gilberto Freyre, que também servem de fonte teórica para a referia escola (MARICATO, 2011, p. 130-135)

Como arremate, o que a autora anuncia como fim do ciclo, tem como cenário a constatação de que apesar dos avanços e conquistas nos âmbitos acadêmicos, institucionais e democráticos, não se pôde verificar a correlata diminuição das desigualdades nas cidades, sendo que, neste aspecto, as conquistas mostraram-se como incapazes de alterar efetivamente a realidade social marcada pela pobreza.

No campo teórico, esta constatação da discrepância entre o que a realidade do que se estudava e aquilo que era academicamente produzido, escancarou a necessidade de se deixar de lado "ingenuidade" promovida pelas teorias desenvolvimentistas de superação do atraso pela superação da condição de subdesenvolvimento. A política econômica adotada pelo país e os efeitos da globalização na sociedade brasileira, propiciaram cada vez mais a deterioração das condições urbanas, como, por exemplo, o aumento da taxa de desemprego e a diminuição de arrecadação de impostos, as quais somavam-se às políticas de ajustes fiscais impossibilitavam uma efetiva solução para os problemas urbanos de moradia, emprego e saneamento. (MARICATO, 2011, p. 145-151)

Para superação desta condição, a autora sugere apostar em uma juventude que esteja ao lado de movimentos e ONGs, mas que não percam sua independência e crítica como outrora ocorreu, somada a revisita ao pensamento crítico da Escola Brasileira de Urbanismo, que apesar de antiga e chamada de clássica, "aborda questões não resolvidas até os dias atuais" (MARICATO, 2011, p. 162-168)

Como citar: DOS SANTOS, Rodolfo Carvalho Neves. MARICATO, Ermínia. Formação e impasse do pensamento crítico sobre a cidade periférica Em: O impasse da política urbana no Brasil. Petrópolis, RJ: Vozes, 2011. Scientia Iuris, Londrina, v. 25, n. 1, p. 200-202, mar. 2021. DOI: $10.5433 / 2178-8189.2018 v 22 n 2 p 200$. ISSN: $2178-8189$. 